\title{
原子力施設災害における救助活動用担架構成ロボットの開発
}

\author{
岩 野 優 樹*1 大須賀 公 一*1 天 野 久 徳*2
}

\section{Development of Stretcher Component Robots for Rescue against Nuclear Disaster}

\author{
Yuki Iwano*1, Koichi Osuka*1 and Hisanori Amano*2
}

\begin{abstract}
This paper studies the rescue robots to rescue people in an area polluted with radioactive leakage in nuclear power institutions. In particular, we propose the rescue system which consists of a group of small mobile robots. First, small traction robots set the posture of the fainted victims to carry easily, and carry them to the safety space with the mobile robots for the stretcher composition. In this paper, we confirm that the stretcher component robots could transport and convey a $40[\mathrm{~kg}]$ dummy doll. And, we also show an application usage of stretcher robot.
\end{abstract}

Key Words: Rescue Robotics, Stretcher Robot, Rescue Tool

\section{1.はじめに}

近年, 科学技術の急速な進歩・高度化に伴い, 災害も非常に 規模が大きく，さらに多様化・複雑化するようになってきてい る。そのため，災害が徐々に消防隊員（ヒト）の手に負えなく なりつつあるのが現状である，特に，1999 年 9 月茨城県東海 村で発生した JCO 事故などの放射線漏洩事故は, 救助隊員の 生命を脅かすものである。そして現実に，救急出動要請で出場 した消防隊員が，現場に取り残された作業員を助け出そうとし， 被ばくするという事例が報告されている。この事故をきっかけ に，現在の原子力施設等における災害対策システムが問題視さ れ，その重要性が再認識されてきている。そして現在，国内外 で様々な研究開発が進められている [1] [4] が，いずれの災害 対策システムも，情報収集，移動経路の確保，パイプの切断や 重量物の搬送等，災害の抑制を主眼としており，救助活動を主 な目的としていない.

そこで，本研究では，一般の原子力関連施設等における事故 などによって，現場から自立的に逃避できない人体を，救助隊 員に代わり事故発生源から遠ざけるための救助ロボットの構成 について考察することを目的とする，具体的には，小型旁引口 ボット群を用いて倒れている要救助者の姿勢を搬送しやすいよ うに整える。その後, 担架構成ロボットにより, 安全な場所へ と搬送する一連の救助システムを構築し，その有効性について 検討する.

\footnotetext{
原稿受付 2005 年 2 月 25 日

*1 神开大学

*2消防研究所

${ }^{* 1}$ Kobe University

${ }^{* 2}$ National Research Institute of Fire and Disaster Japan
}

筆者らは,これまで小型率引ロボット群による要救助者の姿 勢変換作業について述べてきた [8]. 本稿では，その姿勢を整え た要救助者を移送し，安全な場所まで搬送する担架構成ロボッ トの提案およびその試作，実験結果について述べる。また，複 数台のロボットを一つのコントローラで操作するシンプルな操 縦系について考案する。さらに，試作した担架構成ロボットの 担架部分を, 救助活動のツールとして応用利用が可能かどうか についても検討する.

本論文は，2 章で想定する災害現場で有効なロボットの構成 について述べ，そのロボットによる救助システムの流れを紹介 する. 3 章で要救助者の移送と搬送を行う担架構成ロボットの 提案と試作結果について述べ，4章でそのロボットを用いた実 験的検証を行う。そして，5章で担架ロボット単体の応用利用 の検討後, 6 章でまとめという構成となっている.

\section{2. 基本コンセプト}

本章では，想定する災害現場で有効なロボットの構成につい て述べる。

\section{1 ロボットのサイズと形態}

本研究で想定している災害現場は，いわゆる震災現場とは異 なり，通路に瓦磁が大量に散乱していることは少なく，床面は比 較的フラットである.しかし, 建物内ということから通路や階段 部は非常に狭いということが特徵である。これまでに，このよう な現場で作業を行うロボットのサイズ・形態として, Table 1 に 示寸観点から複数の小型ロボットが有効であると述べてきた [7]. このことから，筆者らは小型ロボット群による救助システムに ついて考察する。

\section{2 放射線防護}

次に，もう一つ重要な要素として，放射線漏洩事故での放射 
Table 1 Characteristics of large and small rescue robots

\begin{tabular}{l|c|c|c}
\hline & Large robot & Small robot & $\begin{array}{c}\text { Group of } \\
\text { Small robots }\end{array}$ \\
\hline Approach to the site & Difficult & Easy & Easy \\
\hline $\begin{array}{l}\text { Operation error } \\
\text { influence for victim }\end{array}$ & Serious & Slight & Slight \\
\hline Output power & Large & Small & Large \\
\hline Functions & Many & Few & Many \\
\hline
\end{tabular}

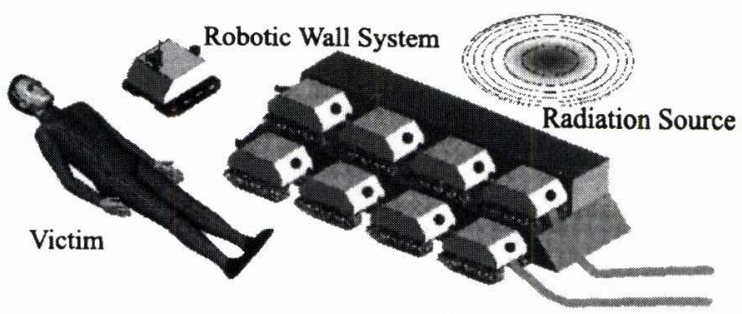

Fig. 1 Robotic wall system

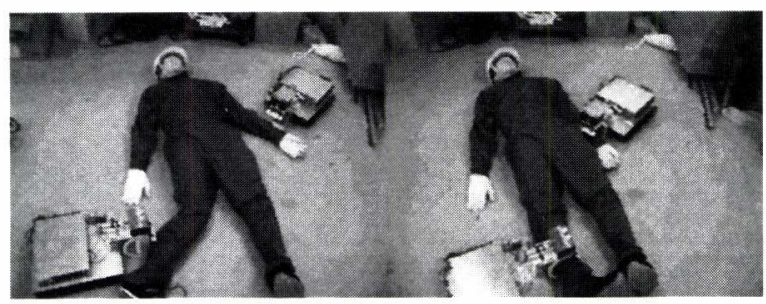

Fig. 2 Posture manipulation

線による被ばくの低減化について考察する。放射線による被ば くを防ぐために重要な要素は，「遮へい」「距離」「時間」であ る [5]. その中でも放射線の影響は「距離」の 2 乗に比例して軽 減されるということから, 要救助者を線源から避難させること が, 救助活動において最も効果的であると考える.

以上を踏まえ, 本研究では, 小型ロボット群によって線源か ら要救助者を遠ざける牽引ロボットシステムについて考察する.

[Remark1]「遮へい」に関しては, Fig. 1のように小型移 動ロボット群によって放射線源と要救助者の間にウォーターバッ クの壁を配置するシステムが, 消防研究所において研究・開発 されている [6].

\section{3 レスキュー戦略}

ここで, 小型ロボット群によって線源から要救助者を遠ざけ る毫引ロボットシステムの流れの一例を紹介する [7].

Step1 情報収集：施設内のカメラ, あるいはカメラを搭載し たロボットが現場へ行き, 要救助者およびその周辺の画像を入 手（要救助者の姿勢情報を主に）

Step2 ロボットの移動：救助を行うロボットが現場まで移動 (ロボットが自走するか，他のロボットに積載し現場へ移動する）

Step3 姿勢変換：要救助者の姿勢を搬送しやすいように，あ るいは担架に乗せやすいように整える

Step4 要救助者の移送・搬送: 姿勢を整えた要救助者を担架 へ移送し, 安全な場所へと般送する

前述したように, Step1，2に関しては，すでに研究開発が 行われていることから, Step3 以降について考える. Step3は, Fig. 2 のように小型率引ロボット群を用いて要救助者の姿勢変
換を行い，担架に移送しやすい姿勢へと操作する作業であり，研 究が進められている [8].

そこで, 本稿では, Step4の姿勢変換後の要救助者を移送し, 搬送するための担架構成ロボットについて述べる。

\section{3. 担架構成ロボットの提案}

本章では，要救助者を移送・搬送する担架構成ロボットにつ いて提案し, 試作結果について述べる.

\section{1 救助方法の検討}

まず，現場から遠ざける手段として，以下のような方法が考 えられる。

・そのまま引きずって運ぶ

・担架に乗せて運ぶ

・抱きかかえて運ぶ

ここで, 最も重要なのは, 小型ロボットを用いるため低出力 で実現できる方法が望ましいということである。このことを踏 まえ，上記方法を検討する.

一目のそのまま引きずって運ぶという方法は, 要救助者と 地面との間の摩擦が小さい場合はそれほどエネルギーを要せず 搬送可能であると考えられる。しかし, 摩擦が大きい場合, 搬 送に高出力が必要となり, 段差の影響も顕著に現れる。また, 移 動距離が長くなると, 全体的に非効率となるうえに, 要救助者 を長距離引きずって運ぶということは, 救助される側としても 良い方法とは考え難い。

次に, 担架に乗せて運ぶことについて考える. 要救助者の体 全体，あるいは一部でも担架に乗せることができれば，地面と の摩擦は軽減される。 そのため, 低出力のロボットでも搬送は 可能となる. しかし, 要救助者を担架に乗せる, あるいは担架 を要救助者の体の下に滑り达ませるという作業は必要である. 二つの方法を比較した場合, 担架に乗せるという作業は, 要救 助者を持ち上げる作業が伴い, それに要する出力は大きくなる. 一方, 担架を体の下に滑り込ませる作業は, 比較的低出力で行 えると考える。

最後に, 抱きかかえて運ぶという方法であるが, 担架に乗せ る場合と同様に, 要救助者を持ち上げるという作業に高出力が 必要となることから, 小型ロボットでは難しいと考える。また, 持ち上げるという行為は, 要救助者を高所にさらすことになる. そのため, 落下の危険性があるなど, 要救助者に与える心理的 負担は大きくなる。こういった面においても抱きかかえて運ぶ という方法は好ましくない.

以上の理由から, 小型ロボットを用いて要救助者を現場から 遠ざけるには, 担架を体の下に滑り込ませることで担架の上に 乗せ, 搬送する方法が実現の可能性が高いと考え, この方法に ついてさらに検討を進める。

\section{2 担架部分の検討}

次に, 担架を体の下に滑り込ませることについて考察する. まず, 担架の挿入は要救助者への恐怖心を配慮し, 死角（頭側） を避ける。また, 通路幅が狭く, 進行方向に対して断面積を小 さく取りたいことから，搬送時は頭側か足側を先頭とする．横 側からの挿入も考えられるが，挿入方向と搬送方向を同一（方 向転換機構を不要）にするため, 足元から挿入を行う. 


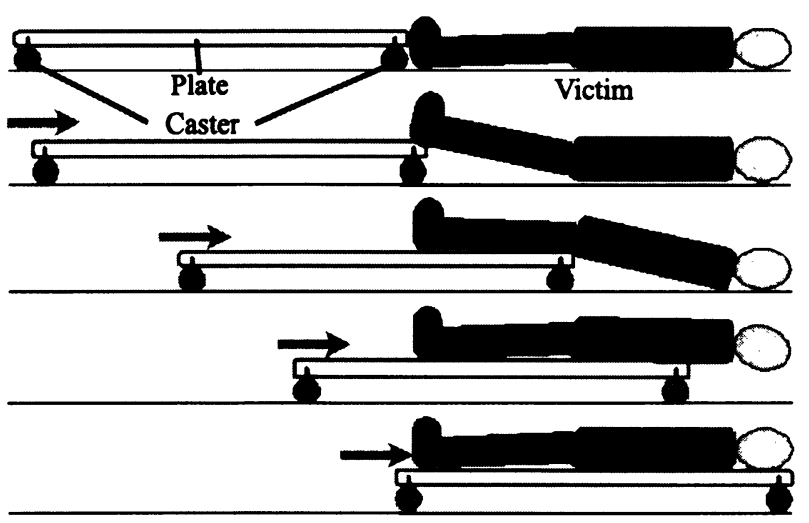

Fig. 3 Simple stretcher

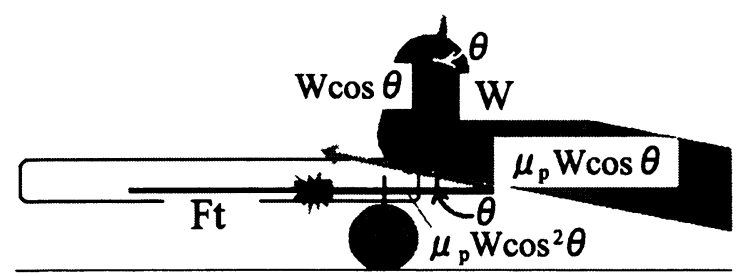

Fig. 4 Dynamics of simple stretcher
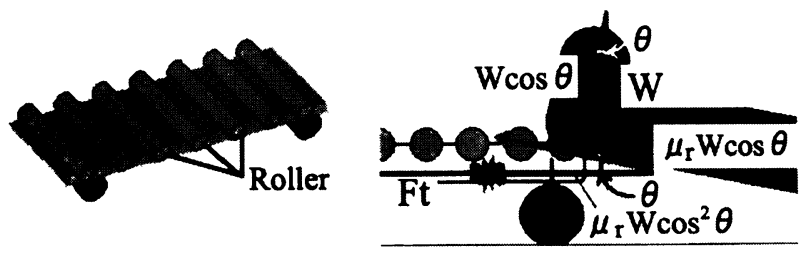

Fig. 5 Stretcher with roller

そこで，まずFig. 3 のように，単純な担架（キャスターの付 いた平板）を体の下に滑り込ませることを考える.

ここで, 要救助者の足が担架にかかった部分（Fig. 3 の上か ら二番目の状態）に注目する. Fig. 4 に体の下に滑り込ませる ための推力と摩擦力の力学的関係を示す.

担架を推力 $F_{t}$ で体の下に滑り込ませる際, 要救助者の重量 $W$ の影響で，担架と体の間に摩擦力 $\mu_{p} W \cos \theta$ が発生する $\left(\mu_{p}\right.$ : 担架と体の間の摩擦係数)。そして, その摩擦力が $F_{t}$ に対し, 反力 $\mu_{p} W \cos ^{2} \theta$ として作用する。 そのため, 担架を体の下に 滑り込ませるためには， $F_{t}-\mu_{p} W \cos ^{2} \theta>0$ を満たす必要が ある.このことから，担架に作用する重量 $W$ が増加する（担 架が体の奥に入り込む）に従い，より大きな推力が必要となる. さらに, 要救助者の体重が重い場合高出力が要求される.つま り，通常の担架では，担架と体との摩擦力が大きいことが原因 で高出力が必要となる.

そこで, 摩擦力を軽隇する機構について考察する. Fig. 5 に示すように担架の上面にローラを配置することで, 摩擦力 を軽減する。こうすることで, 担架と体の間の摩擦係数が $\mu_{r}$ $\left(\mu_{r}<\mu_{p}\right)$ となる.よって，担架を体の下に滑り込ませるため には, $F_{t}-\mu_{r} W \cos ^{2} \theta>0$ を満たす必要がある.

しかし，この場合においても反力がわずかに軽減されるのみ

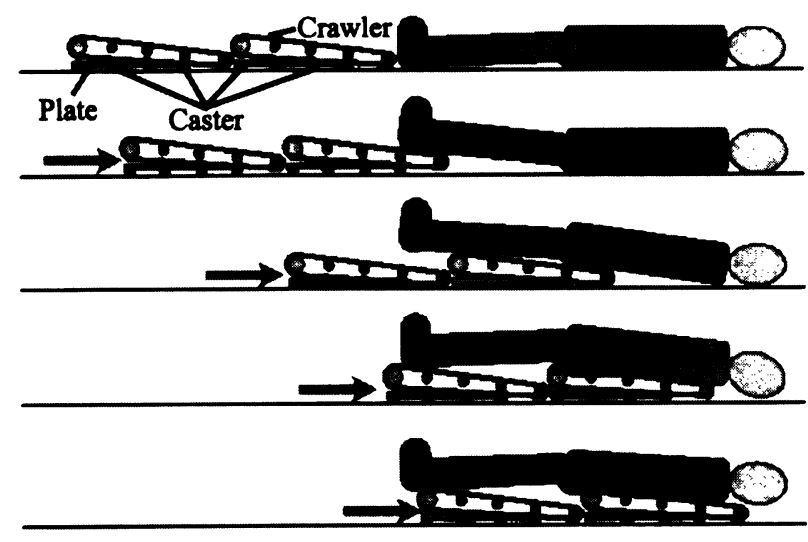

Fig. 6 Concept of stretcher

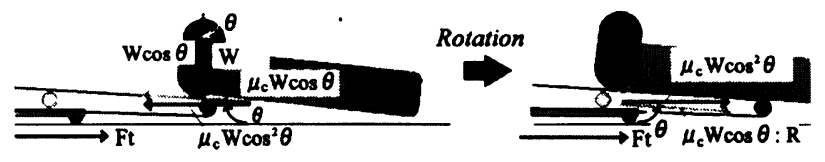

Fig. 7 Feature of stretcher robot

で大幅な改善にならない.そこで，担架の上部にFig. 6 のよう にクローラを取り付ける。そして，そのクローラを回転させな がら, 担架を要救助者の体の下に滑り込ませていくという機構 を提案する。この機構において，担架を滑り込ませる際の力学 的関係を Fig. 7 に示す.なお, Fig. 6 では担架 2 台に体全体を 乗せて運ぶ構造になっているが, 担架 1 台によって体の一部で も浮かすことができれば接地摩擦が軽減されるため, 必ずしも 体全体を浮かすとは限らない.

これまでの担架と同様にクローラと体の間には摩擦力 $\mu_{c} W \cos \theta$ ( $\mu_{c}$ :クローラと体の間の摩擦係数) が存在する. そ して, クローラを反時計回りに回転させることで, その摩擦力 により要救助者を担架の上に引っ張り上げようとする．しかし， 担架の静止摩擦力に対し, 要救助者の静止摩擦力の方が大きい ため, 担架が引つ張られる形で体の下に潜り込むこととなる。つ まり, 通常, 反力として作用する $\mu_{c} W \cos ^{2} \theta$ の力の方向が推 力 $F_{t}$ と同じとなるため, 担架を体の下に滑り込ませる条件は $F_{t}+\mu_{c} W \cos ^{2} \theta>0$ となる. そのため, 従来法とは異なり, 反 力が存在しないうえに, 重量 $W$ が増すにつれて $\mu_{c} W \cos ^{2} \theta$ が 増加し，滑り込む力が強くなるという利点がある。このことか ら, 滑り込ませる方法として適していると考え,この方法を担 架の機構として採用する.

\section{3 担架構成ロボットの構造}

以上を踏まえ，我々が提案する「担架構成ロボット」につい て述べる.「担架構成ロボット」とは, Fig. 8 に示すように, 要 救助者の体の下に滑り込む機構を備えた「担架ロボット」, 担架 構成ロボット全体を駆動させる役割の「轿引ロボット」 2 台と 両者を結合する「ジョイントユニット」の三つのパーツによっ て構成されるロボットのことである．これらの結合は, 担架口 ボットとジョイントユニットをあらかじめ結合しておき, 要救 助者の姿勢変換を終えた牽引ロボットがジョイントユニットを 介して結合するという流れで行う，次節から，各パーツについ 


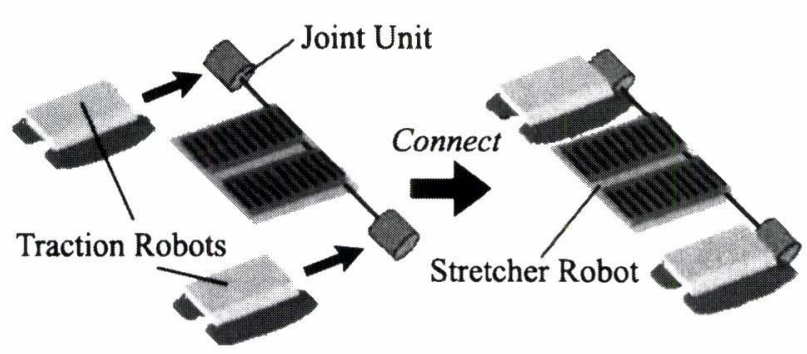

Fig. 8 Stretcher component robot system

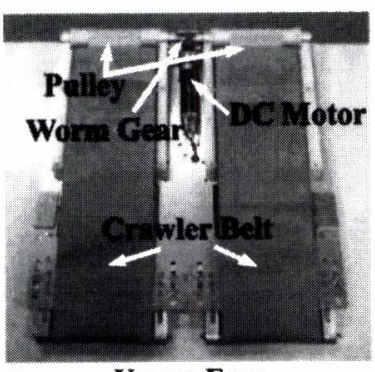

Upper Face

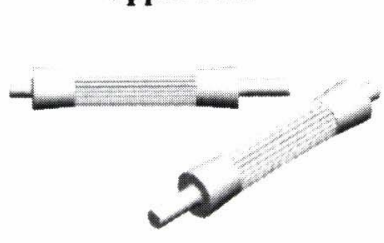

Pulley

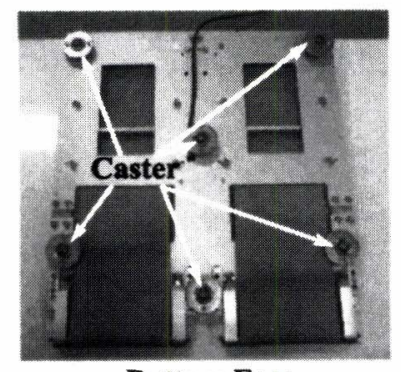

Bottom Face

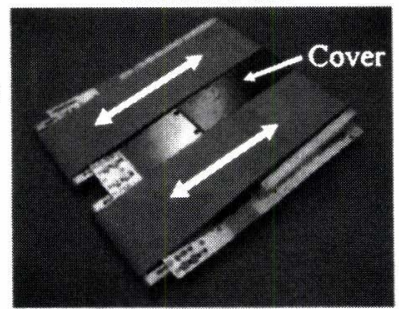

Overviw
Fig. 9 Mechanism of stretcher robot

て詳細に述べる。

\section{4 担架ロボット}

初めに, 担架ロボットの構造と概観を Fig. 9 に示す.

本体中央の DC モー夕を回転させ，その動力をウォームギア を介し，左右のプーリに伝達することでクローラを回転させる 構造になっている (Fig. 9 左上図)。プーリは, 高トルクを受け た際にクローラが外れないよう両端にテーパをつけた形状とし ている (Fig. 9 左下図)。そして, 喠面には地面と担架との接 地摩擦を軽隇するために, 全方位に移動可能な（進行方向に依 存しない) キャスターを 6 個配置する (Fig. 9 右上図)。また, Fig. 9 右下に示すカバーは, 要救助者の体の下に滑り込ませる 際に，衣服などがモータやギア部へ巻き込まないよう配慮した ものである。そして，この担架ロボットは，クローラを回転さ せながら体の下に滑り込ませることで, 重量に対して発生した 摩擦を反力（推進力）として利用し，体の下に滑り达んでいく. この担架ロボットを複数台用い, 要救助者の体の下に滑り込ま せることで移送・搬送を行う。

ここで, 担架ロボットの基本性能（担架に体の一部を乗せる ことで, どの程度要出力が低減されるか）について述べる。体 重を $40 \sim 70[\mathrm{~kg}]$ と変化させたダミ一を平坦なコンクリートの

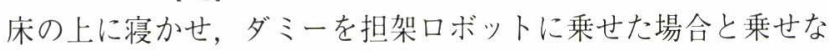
加た場合における, 地面に対して水平方向の最大静止摩擦力 （以下，毫引力）をロードセルで測定する，その結果を Table 2
Table 2 Result of experiment

\begin{tabular}{|c|c|c|}
\hline & \multicolumn{2}{|c|}{ Traction Force (N) } \\
\hline Weight(kg) & Not Use & Use \\
\hline 40 & 218.5 & 83.3 \\
50 & 267.5 & 100.9 \\
60 & 290.1 & 131.3 \\
70 & 357.7 & 147.0 \\
\hline
\end{tabular}

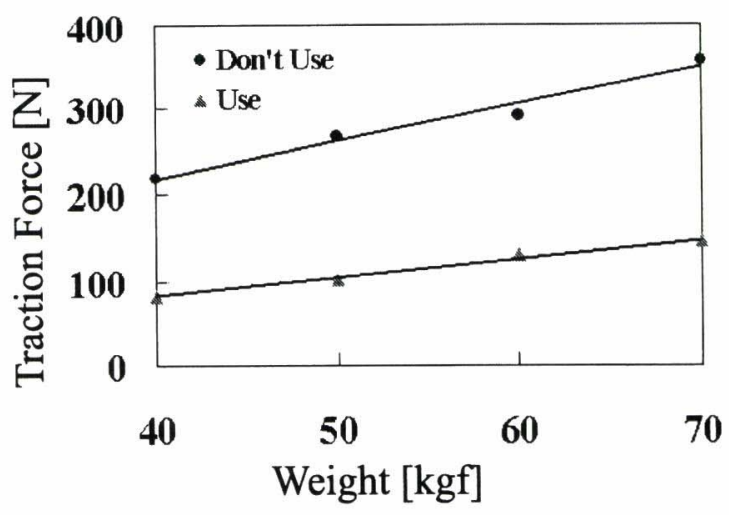

Fig. 10 Effect of stretcher robot to use

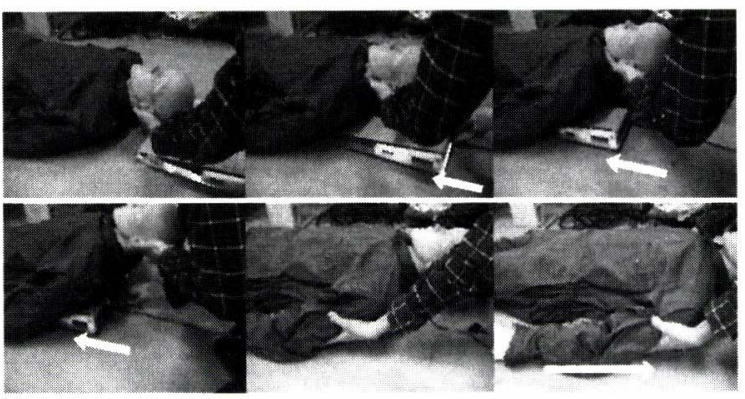

Fig. 11 The example which used the stretcher robot

と Fig. 10 に示す、結果を見ても分かるように，担架ロボット を使うことで，牽引力を軽減できることが分かる，具体的には， $50[\mathrm{~kg}]$ のダミーの毫引力は, 担架なしで行うと $267.5[\mathrm{~N}]$ であ るのに対し, 担架ロボットを滑り込ませて引っ張ると半分以下 の約 $40 \%$ の 100.9 [N] で行えることが分かる.

[Remark2] ここで, 本論文の趣旨とは少しそれるが, 担 架ロボットの応用利用について提案する。この担架ロボットは, Fig. 10 で示したように, 単体で使うことで, 担架ロボットなし で引っ張った場合に比べ，引っ張る力を軽減することができる という特徵がある。その特徽を利用して, Fig. 11 のように, 倒 れている要救助者の背中の下に入れて引っ張ることで, 救助活 動の補助ツールとしての利用が可能であると考える.

これにより, 以下に述べる救助活動での利点を期待する。

(1) 救助隊員 1 人では救助困難な重量のある要救助者を救助可能

(2) 救助活動の迅速化

(3) 救助活動時の人員削減

(4) 救助隊員の体力の温存

今後，この担架ロボットを様々な現場で利用することで，そ の有効性を検証する。特に, 救助隊員のレスキューツールとし ての利用を期待する。 また，その他の状況での応用用途につい 


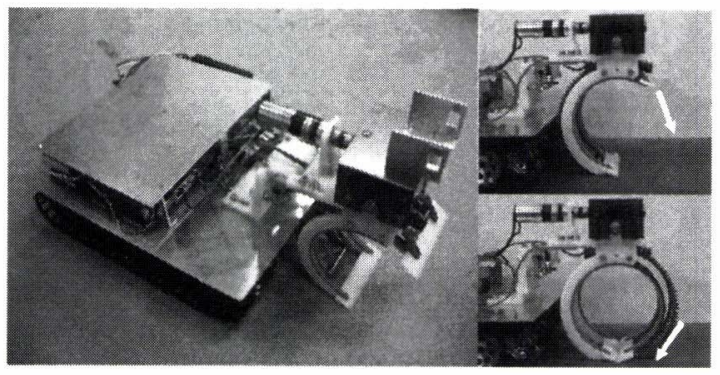

Fig. 12 Traction robot

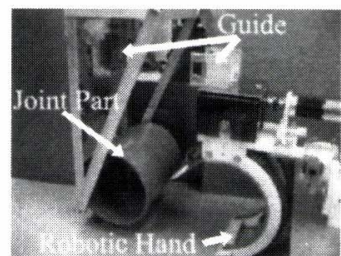

(a)

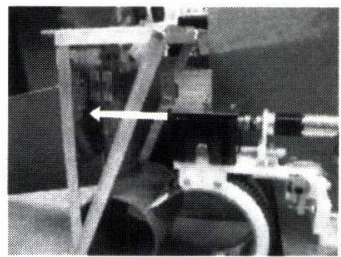

(b)

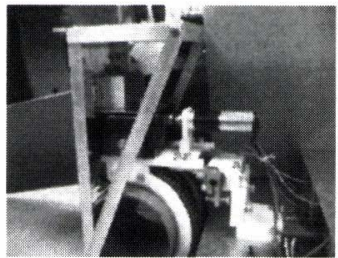

(c)

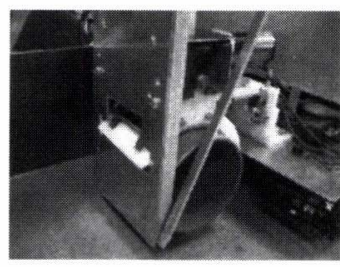

(d)

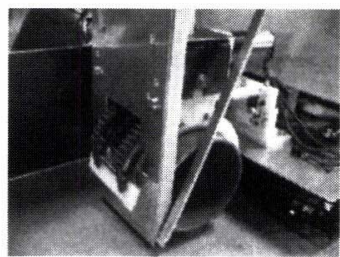

(e)

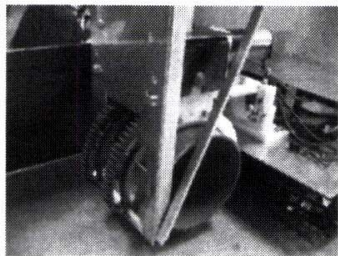

(f)
Fig. 13 Connection mechanism

\section{ても考察する。}

\section{5 牽引ロボット}

次に, ジョイントユニットを介して担架構成ロボットの駆動を 担当する辛引口ボットを Fig. 12 に示す。このロボットは，左 右独立の駆動モータを備えている。また，ロボットの先端には， 率引用のハンドが取り付けてあり, Fig. 12 右図に示すハンドの 開閉と上下動（受動的）の 2 自由度を備えている。ロボットの 毫引力は約 $42.3[\mathrm{~N}]$ である.

このロボットは, 本来要救助者の姿勢変換を行うロボットで ある 8 ．しかし，現場に投入するロボットを極力少なくする， 有効に利用するという目的から，駆動用に新たなロボットを導 入するのではなく，姿勢変換用のロボットをそのまま使えるよ うジョイントユニットを工夫した。

3.6 ジョイントユニット

ジョイントユニットは, 担架ロボットと毫引ロボットを結合 するためのものである。牵引ロボットがジョイントユニットと 結合する様子をFig. 13 に示す. Fig. 13 (a)〜 (c) で，ロボット

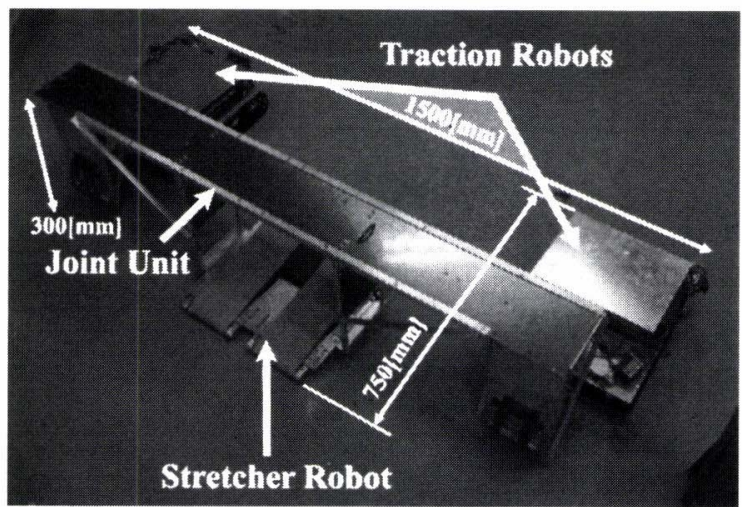

Fig. 14 Overview of stretcher component robots

Table 3 Specification of stretcher component robots

\begin{tabular}{|c|c|c|}
\hline $\begin{array}{c}\text { Weight } \\
{[\mathrm{kg}]}\end{array}$ & $\begin{array}{c}\text { Stretcher Robot } \\
\text { Joint Unit } \\
\text { Traction Robots }\end{array}$ & $\begin{array}{c}3.5 \\
4.9\end{array}$ \\
\hline & Total & 15.3 \\
\hline \hline Size & Stretcher Robot & $400 \times 360 \times 60$ \\
$\mathrm{~L} \times \mathrm{W} \times \mathrm{H}$ & Joint Unit & $60 \times 1300 \times 320$ \\
{$[\mathrm{~mm}]$} & Traction Robot & $580 \times 305 \times 230$ \\
\hline & Total & $750 \times 1500 \times 300$ \\
\hline \hline Motors & & $12 \mathrm{~W}$ DC Motor \\
& Stretcher Robot & 1 \\
& Traction Robots & $3($ Drive:2,Hand: 1$) \times 2$ \\
\hline & Total & 7 \\
\hline
\end{tabular}

がジョイント部まで移動し，ハンド上部のメスのガイドをジョ イントユニット側のオスのガイドに押し込むことによりジョイ ントユニットと結合する. その後, Fig. 13 (d) 〜 (f) でハンドを 閉じ，ジョイント部を把持することで結合を完了する。ジョイ ント部は，ハンドの把持面積を多く取るため円筒状としている.

3.7 担架構成ロボットの諸元

担架構成ロボットの概観を Fig. 14 に，仕様を Table 3 に示 す。中央に担架ロボットとジョイントユニットを配置し, ジョイ ントユニットの両端には, 率引ロボットが結合する構成となっ ている。

また, 担架構成ロボットの基本性能は, 以下のとおりである. 基本性能

- 走行速度 : 約 $1.5[\mathrm{~km} / \mathrm{h}]$

・段差乗り越え：高さ $30[\mathrm{~mm}]$, 幅 $200[\mathrm{~mm}]$ (テーパがある 段差の場合, 高さ $65[\mathrm{~mm}]$ まで乗り越え可能)

・スロープ昇降：最大斜度 $28.0^{\circ}$

[Remark3] Table 3 を見ても分かるように，施設内で作業 する小型の移動ロボットとして，幅 $1,500[\mathrm{~mm}]$ は大きいと考え る。しかし，本稿では，担架にクローラを取り付け，体の下に 滑り込ませる機構の検討を重視している。そのため，ここでは 寸法に関して論じない。今後，横幅が大きいことによる作業上， の不備が生じる場合, 担架ロボット本体に移動機構を取り付け ることでサイズの問題は解消すると考えている.

\section{8 ロボットの操縦系}

ロボットの操縦系を Fig. 15 に示す.ロボットは無線のコン

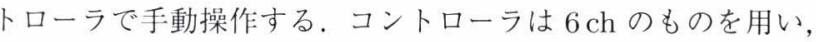




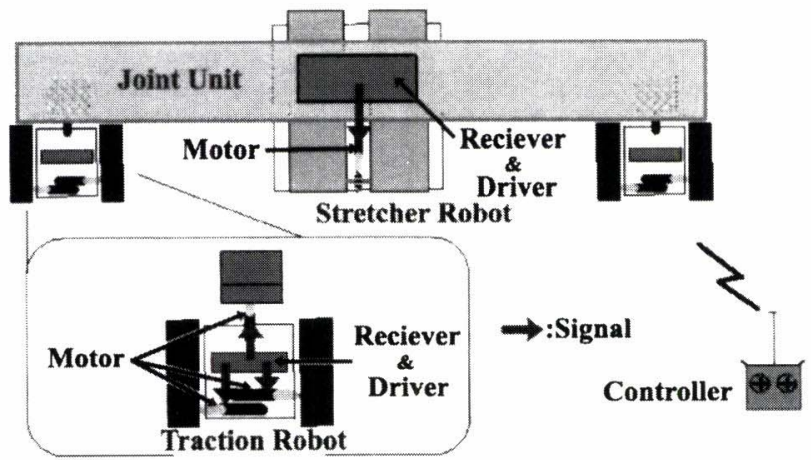

Fig. 15 Operation system of stretcher component robots

ロボットの移動に $2 \mathrm{ch} \times 2$ 台，さらに毫引ロボットのハンドの 開閉に $1 \mathrm{ch}$ ，担架ロボットのクローラの回転に $1 \mathrm{ch}$ 用いる。 ントローラからの指令を牵引ロボットと担架ロボットの受信機 で受信し，ドライバを介して，牽引ロボットの駆動とジョイン トユニットとの結合 (ハンドを閉じる), 担架ロボットのクロー ラの回転を制御するというシンプルな構造となっている。この ことにより，複数台のロボットを，台数分のコントローラで操 作することなく一つのコントローラのみで，すなわち 1 人で操 作が可能となる.

\section{4. 実験}

本章では，製作した担架構成ロボットを用いて実験を行い，そ の有効性を検証する。

まず，平坦なコンクリートの床の上に，直立姿勢に整えた約 $40[\mathrm{~kg}]$ のレスキューランディー [9]（以下，ダミー）を寝かせる. そして，オペレータが目視でロボットの操作を行い，ダミーを 移送・搬送できるかどうか確認する。実際は，カメラ映像を頼 りに遠隔地から操作を行うが，本実験では機構の有効性の検証 を目的としているため，目視での操作とする。なお，才ペレー 夕は, ダミ一の足元後方 $3[\mathrm{~m}]$ の位置から操作を行う. 実験の 様子を Fig. 16 に示す。クローラを回転させつつ，ロボットを ダミ一の足元から体の下に滑り达ませ，肩が浮く位置まで滑り 达ませた後クローラを止めてダミーを搬送する。結果から分か るように，40[kg]のダミーを移送・搬送することが確認でき， その作業に要した時間は約 50 [sec] であった。実際の要救助者 の多くは意識がなく，首が固定されていないため，担架を頭の 下まで滑り迟ませ，頭から背中にかけて支持することで対応す る。また，手足をそのまま引きずることに関しては，施設内の作 業員は全員作業服を着用しており，肌が露出していることはほ とんどないことから影響はないと考える．以上のことから，提 案する担架構成ロボットの移送・搬送に関する機能を確認でき た。また，当初は 2 台の担架構成ロボットを用いる予定であっ たが，1台で搬送が可能であったため本実験では 1 台のみを用 いた．今後は，複数台用いることで 1 台当たりの負担を軽減す る, あるいはさらに重量のあるダミーを用いて実験を行う。

\section{5.おわりに}

本研究では，一般の原子力関連施設等における事故などによっ
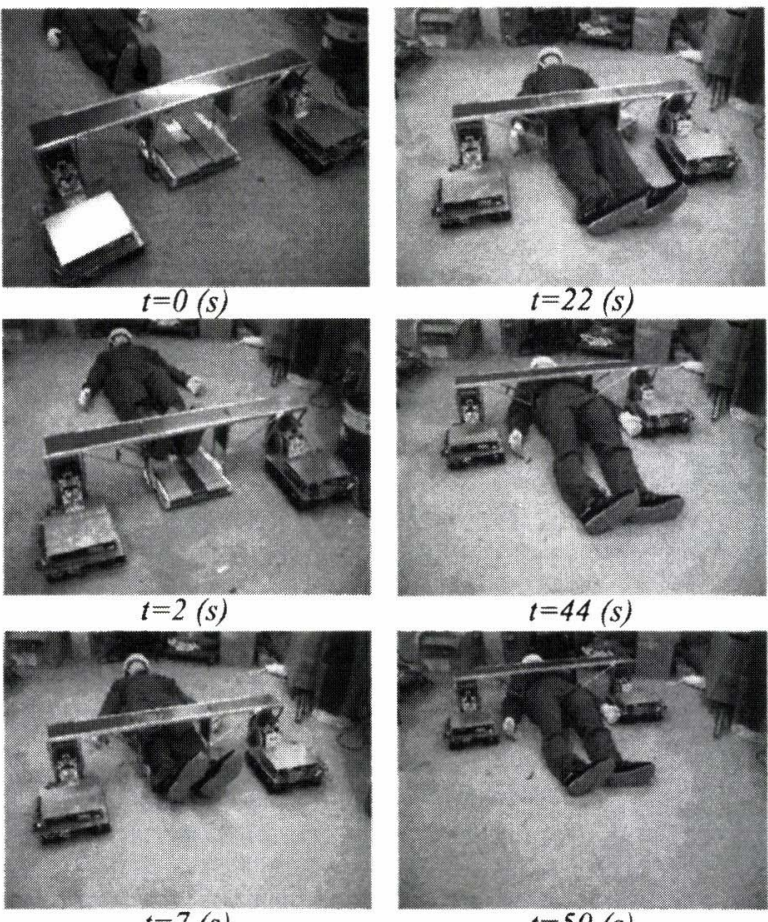

$t=50(s)$

Fig. 16 Experimental result

て，現場から自立的に逃避できない人体を，救助隊員に代わり 事故発生源から遠ざけるための小型ロボット群による救助シス テムの構築を目的としている。

本稿では, その救助システムの一プロセスである, 姿勢を整 えた要救助者を移送し, 安全な場所まで搬送する担架構成ロボッ トの提案と試作結果について述べた。 そして, その担架構成口 ボットを用いて奏験を行った結果, 約 $40[\mathrm{~kg}]$ のダミーを移送し て搬送することができたことから，その有効性を確認した。ま た，複数台のロボットを一つのコントローラで操作するシンプ ルな操縦系を考案した。 さらに, 担架ロボット単体を救助活動の ツールとして利用可能かどうかについて考察した。この担架口 ボットを要救助者の体の下に滑り込ませて引つ張ることで, 毫 引力が半分以下に軽減されることが確認できた。このことから， 救助活動において利用可能であると考える.

今後, 要救助者の姿勢変換から移送・搬送までの総合的な救助 システムの完成を目指すとともに，担架ロボットのレスキュー ッール以外の用途についてもさらに検討する。

\section{参 考 文 献}

１１］濱田彰，間野隆久：“欧米に抢ける原子力防災ロボットの調査報告”, 日本ロボット学会誌, vol.19, no.6, pp.678-684, 2001.

[2] 小林忠義, 宮島和俊, 柳原敏：“原研に扮ける事故対応ロボットの開発 (その1）情報遠隔仪集ロボットの開発”, H本ロボット学会誌, vol.19, no.6, pp.706-709, 2001

[3]間野隆久, 濱田彰 : “原子力防災支援システムの開発”, H本ロボッ 卜学会誌, vol.19, no.6, pp.714-721, 2001.

[4] 磯崎芳史, 中井公一：“原子力防災支援システム開発 作業ロボット および重量物運搬用ロボットの開発”, SICE SI2002 講演論文集 II, pp.99-100, 2002.

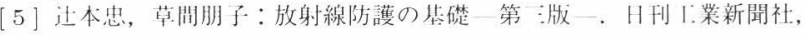


pp. 121-129, 2001.

[6] 天野久徳, 大須賀公，岩野優樹：“防護壁を構成する小型ロボット群 の開発—連結と壁構築機構の検討—”, 日本機械学会ロボティクス. メカトロニクス講演会 '04 講演論文集, no.04-4，1P1-H-43， 2004.

[7] 岩野優樹，大須賀公一，天野久德，菊地孝司：“小型毫引ロボット群に よる救助活動のための動作計画について一人体姿勢マニピュレーショ ンアルゴリズムの構築と実装—”，第 8 回ロボティクス・シンポジア
予稿集, pp.301-306, 2003.

[8] Y. Iwano, K. Osuka and H. Amano: "Proposal of a Rescue Robot System in Nuclear-Power Plants-Rescue Activity via Small Vehicle Robots-," Proceedings of 2004 IEEE International Conference on Robotics and Biomimetics, no.268, 2004.

[9] http://www.eva.hi-ho.ne.jp/medical/rescue.htm

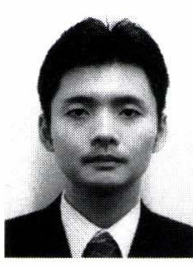

\section{岩野優樹（Yuki Iwano）}

1978 年 2 月 20 日生. 2002 年滋賀県立大学大学院 工学研究科機械システム工学専攻修士課程修了. 同 年京都大学大学院情報学研究科システム科学専攻 博士後期課程入学. 2004 年神戸大学大学院自然科 学研究科システム機能科学専攻博士後期課程に転入 学. 現在に至る。 (日本ロボット学会学生会員)

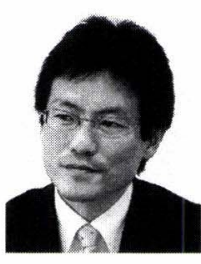

\section{大須賀公一（Koichi Osuka）}

1959 年 11 月 16 日生. 1984 年大阪大学大学院基 礎工学研究科修士課程修了. 同年 (株) 東芝入社, 総合研究所勤務. 1986 年大阪府立大学工学部助手. その後同講師，同助教授を経て，1998 年京都大学 大学院情報学研究科助教授, 2003 年神戸大学工学 部機械工学科教授となり, 現在に至る。工学博士.

(日本ロボット学会正会員)

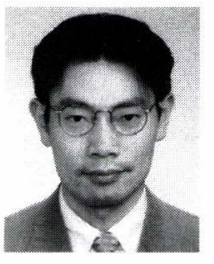

天野久徳 (Hisanori Amano)

1964 年 2 月 5 日生. 1988 年大阪府立大学工学部機 械工学科卒業. 博士 (情報学). 同年自治省消防庁消 防研究所入所. 2000 年第三研究部主任研究官. 2001 年組織改組により独立行政法人消防研究所基盤研究 部主任研究官. 2004 年同消防機械研究グループ長, 現在に至る。1995１996 年千葉大学，1998～1999 年ワシントン大学客員研究員. 消防・救助ロボットおよび消防用機器 の振動制御の研究に従事.

（日本ロボット学会正会員） 